\title{
On Workplace Investment in Employee Well-Being
}

\author{
Bulmash Ben $^{1 *}$ \\ ${ }^{1}$ University of Massachusetts Amherst, Isenberg School of Management, USA \\ *Bulmash Ben, E-mail: bbulmash@som.umass.edu
}

Received: Novermber 5, 2016 Accepted: Novermber 18, 2016 Online Published: Novermber 22, 2016

doi:10.22158/rem.v1n2p166 URL: http://dx.doi.org/10.22158/rem.vln2p166

\begin{abstract}
Many modern organizations invest substantially in employee well-being, especially knowledge-intensive companies. However, decision makers fail to make informed choices based on theoretical advancements and empirical evidence provided by years of high-quality research on individual well-being. This study reviews five fundamental scientific principles regarding people's experiences of well-being and discusses the possible implications of the findings on organizational well-being initiatives. My purpose is to encourage organizations and decision makers to make more effective evidence-based investments in employee well-being.
\end{abstract}

Keywords

well-being, happiness, investment in workers, human resource management, literature review

\section{Introduction}

Work is unquestionably a dominant aspect of life and is often considered to be one of the least pleasant activities of the day. Commuting, interacting with the boss and co-workers, and being alone for prolonged periods were ranked among the least enjoyable work activities. Thus, many employers attempt to enhance employee well-being to make work more attractive and pleasant. SAS, the best ranked employer in 2010 (CNN-Money, 2010), offers its employees a gymnasium, billiard hall, sauna, massages, hair salon, Olympic-size pool, and many other perks. Such huge investments in worker wellness demonstrate the employers' attempt to ease some of the stresses associated with the modern workplace. Notably, investment in employee well-being is highest among knowledge-intensive companies such as Google, SAS, and The Boston Consulting Group, which comprise the top 3 companies to work for in 2014 (http://www.fortune.com/best-companies/). The reason for this investment by knowledge-intensive firms is that workers comprise the most valuable asset in these companies, and loyalty is considered extremely important in consideration of the sensitivity of the information in these organizations.

These large investments in workers may prove beneficial from an internal and external marketing sense for the sake of attracting and retaining employees, but it is not clear whether they actually contribute to 
workers' experienced well-being. In addition to the inherent value in worker well-being, research lends support to the happy/productive worker thesis. Namely, well-being is significantly associated with improved performance, enhanced creativity, and supportive organizational behaviors. According to the broaden-and-build theory (Fredrickson, 2001), well-being broadens individuals' though-action repertoires. Thus, when a broad scope of attention and cognition is needed, positive emotions prompt individuals to engage with their environment while also promoting flexible and creative thinking (Ashby \& Isen, 1999; Fredrickson \& Branigan, 2005; Isen, 1999).

The purpose of this study is to examine the effectiveness of well-being investments made by organizations in terms of increasing employee well-being. The underlying goal is to improve scholars' and practitioners' understanding of well-being and explain the conditions under which organizational investments have the greatest merit. This review is timely and important given the growing interest in employee well-being in recent years.

\section{Part 1-Five Fundamental Scientific Principles on SWB}

The growing investments in worker well-being indicate employer understanding that happy workers add more value to the business. Happy workers provide better service to customers, contribute from their knowledge and skills to other employees, and contribute to the overall image of the organization. The question employers may ask, however, is how to make their workers happier. According to Lyubomirsky (2008), it is relatively easy to generate happiness for a short duration, but the challenge lies in sustaining a higher level of happiness. The following sections summarize five key findings in the research on experienced or Subjective Well-Being (SWB).

\subsection{Bad is Stronger than Good}

According to Resick, Giberson, Dickson, Wynne and Bajdo (2013), "People find relevant cues about an organization's environment through the characteristics of other members... and the organization's goals, structures, systems, and practices" (p. 104). Specifically, individuals attend to episodes that provide relevant information regarding potential success, failure, pleasure, or pain. In terms of SWB, the event is as important as the information embedded in it. Moments rich with self-relevant information will dominate people's global evaluations of their SWB (Fredrickson, 2000). Within the spectrum of relevant information, Tversky and Kahneman (1991) propose that people are more sensitive to lossthan to gain-related information. To account for this phenomenon, Baumeister, Bratslavsky, Finkenauer and Vohs (2001) termed the phrase, "Bad is stronger than good". Negative emotions have more impact on individuals than positive ones. This explains why negative effects at work are not always moderated by opposing positive effects (Duffy, Ganster, \& Pagon, 2002).

\subsection{The Recency Bias}

People are sensitive to the most recent events (Fredrickson, 2000). In experiments of pain and pleasure, people give higher ratings to less overall pleasure than to more overall pleasure, depending on the way the experiment ends. Similarly, two positive stimuli are given a lower rating than a single positive 
stimulus if the second stimulus is less positive than the first (Do, Rupert, \& Wolford, 2008). Retrospective evaluations of aversive experiences are often dominated by the discomfort at (1) the worst and (2) the final moments of episodes (Kahneman, Fredrickson, Schreiber, \& Redelmeier, 1993). For instance, consider individuals' preferences in accepting good and bad news. Legg and Sweeny (2013) show that news recipients prefer to receive the bad news first, thus ending on a high note. Such recipients were in a better mood and worried less than recipients who heard bad news last. With this logic, a difficult conversation with one's boss is as bad as its worst part as well as its ending. An important point made here is that the duration of the affective episodes has little effect on people (Fredrickson \& Kahneman, 1993).

\subsection{The Status Quo as Reference}

Another important finding is that individuals evaluate their well-being in reference to the status quo (Tversky \& Kahneman, 1991). Therefore, many employers believe that the introduction of new benefits will improve the workers' status quo and in turn increase their well-being. However, research suggests that introducing new material benefits simply creates a new status quo to which people adapt and use as reference once it is established (Easterlin, 2005). Similarly, the higher a person's income is, the higher the amount of money seems to be required to "get along" (Rainwater, 1994). And since people are loss averse (Tversky \& Kahneman, 1991), any deterioration from the new and improved status quo is likely to result in a decrease in experienced well-being.

\subsection{Other People as Reference}

Individuals' SWB reference point is socially dependent. People tend to compare their situation to their most immediate neighbors (Easterlin, 1974, 1995). It was shown that higher earnings of neighbors are associated with lower levels of self-reported happiness (Luttmer, 2005). Individuals are less likely to be around those whose income is very different or distant from theirs, and their comparison group is therefore more likely to be one of a similar income level, making any difference in income more immediately visible (Diener, 1995). In organizations, workers tend to work closely with those who have similar wages and work conditions. Any difference in pay would then be noticeable. Interestingly, research shows that promotion has only a temporary positive effect on job satisfaction (Kosteas, 2011). A suggested explanation is that promoted individuals do not immediately establish their new comparison group, but rather increasingly compare themselves to the new peers as a reference point (Kahneman, Krueger, Schkade, Schwarz, \& Stone, 2006), to the point that the status quo is redefined and the new comparison group is fully established. This leads us to the next well-established concept of the hedonic treadmill.

\subsection{The Hedonic Treadmill: A Set Point for Happiness}

Research has repeatedly demonstrated that feelings tend to return to their original baseline after emotionally charged life events (Headey \& Wearing, 1989). This finding seems to be consistent for almost any event, big or small, positive or negative (Brickman, 1978; Lucas, Clark, Georgellis, \& Diener, 2003; Lyubomirsky, 2008; Suh, Diener, \& Fujita, 1996). It was shown that people also adapt to 
severe and enduring health conditions (Riis et al., 2005). These findings led scholars to suggest that "[w]e cannot allow our happiness to depend on our external circumstances, for every positive event and accomplishment we experience are accompanied by rapid adaptation and escalating expectations" (Lyubomirsky, 2008). Brickman and Campbell (1971) named this effect "the hedonic treadmill", where people cannot do much to change their long-term levels of SWB.

Twin studies suggest there is a happiness "set point" for individuals and that this set point is predetermined to a large extent. This predetermined set-point is suggested to explain between 40 and 80 percent of our variance in happiness (Lykken \& Tellegen, 1996; Tellegen et al., 1988). Namely, if one's environment is relatively constant, one's SWB could be explained to a large extent by one's genetics (Diener, Suh, Lucas, \& Smith, 1999). However, if the environment is chaotic and unstable, such as in the case of major social or economic turbulence (Bulmash, Saporta, \& Ganzach, 2014), situational attributes are likely to impact one's well-being to a much larger extent. The treadmill effect is an accepted phenomenon that has very clear implications for employers: increases and decreases in SWB may be short-lived. This fact seems especially true in regard to material benefits such as income (Easterlin, 2005; Rainwater, 1994). Despite the fact that people report that "more money" would definitely enhance the quality of their lives (Campbell, 1981), it was shown that higher income is actually associated with higher ratings of anger and anxiety. Thus, higher income may be associated with experienced negative emotions and not greater experienced happiness (Kahneman, Krueger, Schkade, Schwarz, \& Stone, 2006). Nevertheless, income increases may be an important factor when basic material needs are unsatisfied (Akay \& Martinsson, 2011; Biswas-Diener \& Diener, 2001). However, beyond a surprisingly modest threshold point, the correlation between income and SWB weakens significantly (Diener, Tay, \& Oishi, 2013; Easterlin, 1974; Inglehart \& Klingemann, 2000; Frey \& Stutzer, 2002; Lane, 2000).

Much of what science tells us about SWB suggests that it may be very difficult to significantly improve workers' well-being. With this in mind, the intention is now to address the question of what can be done to increase employee well-being. Given recent developments in research on SWB, we are in a better position to draw some conclusions regarding more effective techniques and processes that organizations can implement to increase worker well-being.

\section{Part 2-How Can Organizations Increase Happiness?}

Individuals attend to relevant information regarding potential pleasure or pain. Communication may be the most significant mechanism by which such relevant information flows in the organization. Therefore, communication management is likely to be one major source for improving individuals' SWB. In communication management, organizations should pay attention to the continuous flow of information between individuals as well as between the organization and its members in terms of both content and style. While communication can create a healthy and conductive work environment, it can also create a hostile work environment and undesirable organizational climate when used ineffectively. 
If we consider the recency bias, finishing a message on a positive note rather than a negative one may improve workers' SWB. Considering other people as reference, constant comparison between workers (e.g., salary comparison) is a major source of dissatisfaction and unhappiness. Limiting such comparisons among workers may be an important way to promote well-being in the organization. It is important for both human resources and managers in the organization to be aware of the information that is available to workers and to consider the meaning of such information.

Another way to limit workers' access to continuous negative information would be to distract workers from ongoing negative thoughts and stressful appraisals. A state of flow, which refers to a complete absorption in what one does, is considered a major source of happiness (Csikszentmihalyi, 2000). Listening to music while working is one way to promote this state of flow at work (Thayer, Newman, $\&$ McClain, 1994). Another way to "be in the moment" is through meditation. Cumulative evidence indicates that meditation workshops and daily practices can result in elevated mood, as well as improved health and cognitive abilities (Kabat-Zinn, 1990; Shapiro, Schwartz, \& Santerre, 2002; Smith, Compton, \& West, 1995).

In addition to communication management, another way to increase workers' experienced well-being is to regularly introduce positive affective experiences. The underlying rule here is to break repeatedly from the status quo without trying to change it. There is a great variety of possible positive experiences during the day, such as meeting with new people, facing interesting challenges, achieving goals, having breaks from work, and more. As indicated earlier, the duration of the activity is less meaningful than its peak and ending, which make the largest impact on people's SWB. Therefore, in order to sustainably promote SWB in the organization, the organization should repetitively present opportunities for short, pleasant experiences. With a similar line of thought, scholars have suggested that "frequent positive emotions - feelings of joy, delight, contentment, serenity, curiosity, interest, vitality, enthusiasm, vigor, thrill, and pride - are the very hallmark of happiness" (Diener, Sandvik, \& Pavot, 1991). More examples of such repeated activities are mild to moderate exercise and regular religious practice (Mochon, Norton, \& Ariely, 2008; Thayer, Newman, \& McClain, 1994). Activities during which individuals reported the highest positive affect included interacting with friends and family, meditating, and exercising (Kahneman, Krueger, Schkade, Schwarz, \& Stone, 2004). In a similar vein, employers would want to eliminate repeating negative affective experiences, such as incidents of bullying or mistreatment from one's supervisor or peers (Salin, 2003; Tepper, 2007; Lutgen-Sandvik, Tracy, \& Alberts, 2007).

Lastly, if organizations want happy workers, they should incorporate this fact in their recruitment and selection procedures. In addition to considering KSAs (Knowledge, Skills, \& Abilities), human resources can and should also consider general attitudes. The hedonic treadmill effect suggests that individuals have a happiness set point. If organizations recruit members with a higher set point, they will have happier workers, even in the face of adverse circumstances. 


\section{Conclusion}

Contemporary research on SWB suggests that it is rather challenging to promote and sustain high level of happiness. This challenge is even more pronounced in the modern stressful neoliberal workplace, where demands are high and job security is low. As a result, modern organizations spend huge sums of money on well-being initiatives. However, organizations may be spending money in the wrong places when trying to promote workers' well-being. In this paper, I intend to bridge between academia and practice, and argue that understanding fundamental scientific principles can help organizations and decision makers make better, cost-effective, decisions, which can lead to better overall performance and a more sustainable and committed workforce.

\section{References}

Akay, A., \& Martinsson, P. (2011). Does relative income matter for the very poor? Evidence from rural Ethiopia. Economics Letters, 110(3), 213-215. https://dx.doi.org/10.1016/j.econlet.2010.11.046

Ashby, F. G., \& Isen, A. M. (1999). A neuropsychological theory of positive affect and its influence on $\begin{array}{llll}\text { cognition. } & \text { Psychological }\end{array}$ https://dx.doi.org/10.1037/0033-295X.106.3.529

Baumeister, R. F., Bratslavsky, E., Finkenauer, C., \& Vohs, K. D. (2001). Bad is stronger than good. Review of General Psychology, 5(4), 323-370. https://dx.doi.org/10.1037/1089-2680.5.4.323

Biswas-Diener, R., \& Diener, E. (2001). Making the best of a bad situation: Satisfaction in the slums of Calcutta. Social Indicators Research, 55(3), 329-352. https://dx.doi.org/10.1023/A:1010905029386

Brickman, P., \& Campbell, D. T. (1971). Hedonic relativism and planning the good society. In M. H. Appley (Ed.), Adaptation level theory: A symposium (pp. 287-302). New York: Academic Press.

Brickman, P., Coates, D., \& Janoff-Bulman, R. (1978). Lottery winners and accident victims: Is happiness relative? Journal of Personality and Social Psychology, 36(8), 917-927. https://dx.doi.org/10.1037/0022-3514.36.8.917

Bulmash, B., Saporta, I., \& Ganzach, Y. (2014, January). The Cost of Well-Being: The Role of Income Following Social Transition. In Academy of Management Proceedings (Vol. 2014, No. 1, p. 11585). Academy of Management.

Campbell, A. (1981). The sense of well-being in America. New York: McGraw-Hill.

CNN-Money. (2010). SAS: A new no. 1 best employer. Retrieved May 10, 2014, from http://www.money.cnn.com/2010/01/21/technology/sas_best_companies.fortune/

Csikszentmihalyi, M. (2000). Beyond boredom and anxiety. San Francisco: Jossey-Bass Publishers (Original work published in 1975).

Diener, E., Diener, M., \& Diener, C. (1995). Factors predicting the subjective well-being of nations. Journal of Personality and Social Psychology, 69(5), 851-864. https://dx.doi.org/10.1037/0022-3514.69.5.851

Diener, E., Sandvik, E., \& Pavot, W. (1991). Happiness is the frequency, not the intensity, of positive Published by SCHOLINK INC. 
versus negative affect. In F. Strack, M. Argyle, \& N. Schwarz (Eds.), Subjective Well-being: An interdisciplinary perspective (pp. 119-139). Elmsford, NY: Pergamon.

Diener, E., Suh, E., Lucas, R. E., \& Smith, H. L. (1999). Subjective well-being: Three decades of $\begin{array}{lll}\text { progress. } & \text { Psychological }\end{array}$ https://dx.doi.org/10.1037/0033-2909.125.2.276

Diener, E., Tay, L., \& Oishi, S. (2013). Rising income and the subjective well-being of nations. Journal of Personality and Social Psychology, 104(2), 267-276. https://dx.doi.org/10.1037/a0030487

Do, A. M., Rupert, A. V., \& Wolford, G. (2008). Evaluations of pleasurable experiences: The peak-end rule. Psychonomic Bulletin \& Review, 15(1), 96-98. https://dx.doi.org/10.3758/PBR.15.1.96

Duffy, M. K., Ganster, D. C., \& Pagon, M. (2002). Social undermining in the workplace. Academy of Management Journal, 45(2), 331-351. https://dx.doi.org/10.2307/3069350

Easterlin, R. A. (1974). Does economic growth improve the human lot? Some empirical evidence. In Paul A. David, \& Melvin W. Reder (Eds.), Nations and households in economic growth: Essays in honor of Moses Abramowitz (pp. 89-125). New York: Academic Press. https://dx.doi.org/10.1016/B978-0-12-205050-3.50008-7

Easterlin, R. A. (1995). Will raising the incomes of all increase the happiness of all? Journal of Economic Behavior \& Organization, 27(1), 35-47. https://dx.doi.org/10.1016/0167-2681(95)00003-B

Easterlin, R. A. (2005). A puzzle for adaptive theory. Journal of Economic Behavior \& Organization, 56(4), 513-521. https://dx.doi.org/10.1016/j.jebo.2004.03.003

Fortune. (2014). 100 Best companies to work for. Retrieved May 10, 2014, from http://www. money.cnn.com/magazines/fortune/best-companies/

Fredrickson, B. L. (2000). Extracting meaning from past affective experiences: The importance of peaks, ends, and specific emotions. Cognition \& Emotion, 14(4), 577-606. https://dx.doi.org/10.1080/026999300402808

Fredrickson, B. L. (2001). The role of positive emotions in positive psychology: The broaden-and-build theory of positive emotions. American Psychologist, 56(3), 218-226. https://dx.doi.org/10.1037/0003-066X.56.3.218

Fredrickson, B. L., \& Branigan, C. (2005). Positive emotions broaden the scope of attention and thought-action repertoires. Cognition \& Emotion, 19(3), 313-332. https://dx.doi.org/10.1080/02699930441000238

Fredrickson, B. L., \& Kahneman, D. (1993). Duration neglect in retrospective evaluations of affective episodes. Journal of Personality and Social Psychology, 65(1), 45-55. https://dx.doi.org/10.1037/0022-3514.65.1.45

Frey, B., \& Stutzer, A. (2002). Happiness and Economics: How the Economy and Institutions Affect Human Well-being. Princeton University Press: Princeton, New Jersey.

Headey, B., \& Wearing, A. (1989). Personality, life events, and subjective well-being: Toward a dynamic equilibrium model. Journal of Personality and Social Psychology, 57(4), 731-739. 
https://dx.doi.org/10.1037/0022-3514.57.4.731

Inglehart, R., \& Klingemann, H-D. (2000). Genes, Culture, and Happiness. MIT Press: Boston.

Isen, A. M. (1999). Positive affect. In T. Dalgleish, \& M. J. Power (Eds.), The handbook of cognition and emotion (pp. 521-539). New York: Wiley. https://dx.doi.org/10.1002/0470013494.ch25

Kabat-Zinn, J. (1990). Full catastrophe living: Using the wisdom of your body and mind to face stress, pain and illness. New York: Delacourt.

Kahneman, D., \& Krueger, A. B. (2006). Developments in the measurement of subjective well-being. $\begin{array}{lllll}\text { The Journal of } & \text { Economic }\end{array}$ https://dx.doi.org/10.1257/089533006776526030

Kahneman, D., Fredrickson, B. L., Schreiber, C. A., \& Redelmeier, D. A. (1993). When more pain is preferred to less: Adding a better end. Psychological Science, 4(6), 401-405. https://dx.doi.org/10.1111/j.1467-9280.1993.tb00589.x

Kahneman, D., Krueger, A. B., Schkade, D. A., Schwarz, N., \& Stone, A. A. (2004). A survey method for characterizing daily life experience: The day reconstruction method. Science, 306(5702), 1776-1780. https://dx.doi.org/10.1126/science.1103572

Kahneman, D., Krueger, A., Schkade, D., Schwarz, N., \& Stone, A. (2006). Would You Be Happier If You Were Richer? A Focusing Illusion. Science, 5782(312), 1908-1910. https://dx.doi.org/10.1126/science.1129688

Kosteas, V. D. (2011). Job satisfaction and promotions. Industrial Relations: A Journal of Economy and Society, 50(1), 174-194. https://dx.doi.org/10.1111/j.1468-232x.2010.00630.x

Lane, R. E. (2000). The loss of happiness in market democracies (p. 5). New Haven: Yale University Press. See Figure 1.1.

Legg, A. M., \& Sweeny, K. (2013). Do You Want the Good News or the Bad News First? The Nature and Consequences of News Order Preferences. Personality and Social Psychology Bulletin, 40(3), 279-288. https://dx.doi.org/10.1177/0146167213509113

Lucas, R. E., Clark, A. E., Georgellis, Y., \& Diener, E. (2003). Reexamining adaptation and the set point model of happiness: Reactions to changes in marital status. Journal of Personality and Social Psychology, 84(3), 527-539. https://dx.doi.org/10.1037/0022-3514.84.3.527

Lutgen-Sandvik, P., Tracy, S. J., \& Alberts, J. K. (2007). Burned by Bullying in the American Workplace: Prevalence, Perception, Degree and Impact. Journal of Management Studies, 44(6), 837-862. https://dx.doi.org/10.1111/j.1467-6486.2007.00715.x

Luttmer, E. F. (2005). Neighbors as negatives: Relative earnings and well-being. The Quarterly Journal of Economics, 120(3), 963-1002.

Lykken, D., \& Tellegen, A. (1996). Happiness is a stochastic phenomenon. Psychological Science, 7(3), 186-189. https://dx.doi.org/10.1111/j.1467-9280.1996.tb00355.x

Lyubomirsky, S. (2008). The how of happiness: A scientific approach to getting the life you want. Penguin. 
Rainwater, L. (1994). Family equivalence as a social construction. In D. Ekertjaffe (Ed.), Standards of Living and Families: Observation and Analysis (pp. 25-39). Montrouge, France: John Libbey Eurotext.

Riis, J., Loewenstein, G., Baron, J., Jepson, C., Fagerlin, A., \& Ubel, P. A. (2005). Ignorance of hedonic adaptation to hemodialysis: A study using ecological momentary assessment. Journal of Experimental Psychology: General, 134(1), 3-9. https://dx.doi.org/10.1037/0096-3445.134.1.3

Salin, D. (2003). Ways of explaining workplace bullying: A review of enabling, motivating and precipitating structures and processes in the work environment. Human Relations, 56(10), 1213-1232. https://dx.doi.org/10.1177/00187267035610003

Shapiro, S. L., Schwartz, G. E. R., \& Santerre, C. (2002). Meditation and positive psychology. In C. R. Snyder, \& S. J. Lopez (2002), Handbook of positive psychology. Oxford, UK: Oxford University Press.

Suh, E., Diener, E., \& Fujita, F. (1996). Events and subjective well-being: Only recent events matter. Journal of Personality and Social Psychology, 70(5), 1091-1102. https://dx.doi.org/10.1037/0022-3514.70.5.1091

Tellegen, A., Lykken, D. T., Bouchard, T. J., Wilcox, K. J., Segal, N. L., \& Rich, S. (1988). Personality similarity in twins reared apart and together. Journal of Personality and Social Psychology, 54(6), 1031-1039. https://dx.doi.org/10.1037/0022-3514.54.6.1031

Tepper, B. J. (2007). Abusive supervision in work organizations: Review, synthesis, and research agenda. Journal of Management, 33(3), 261-289. https://dx.doi.org/10.1177/0149206307300812

Thayer, R. E., Newman, J. R., \& McClain, T. M. (1994). Self-regulation of mood: Strategies for changing a bad mood, raising energy, and reducing tension. Journal of Personality and Social Psychology, 67(5), 910-925. https://dx.doi.org/10.1037/0022-3514.67.5.910

Tversky, A., \& Kahneman, D. (1991). Loss aversion in riskless choice: A Reference-dependent model. Quarterly Journal of Economics, 106, 1039-1061. https://dx.doi.org/10.2307/2937956 